\title{
Çocuğun İyi Olma Hâlinin Gelișmesinde Sosyoekonomik ve Yönetsel Politikalar: Finlandiya Örneği d
}

\author{
Socioeconomic andManagerial Policies in the Development of \\ Childiren's Well-being: The Caseof Finland
}

\author{
Samed KURBAN \\ Dr. Arș. Gör. Dumlupınar Üniversitesi, \\ Iktisadi ve İdari Bilimler Fakültesi, Kamu Yönetimi Bölümü \\ samedkurban@gmail.com \\ https://orcid.org/0000-0001-6002-1573
}

\section{Araștırma \& Yayın Etiği \\ Bu makale en az iki hakem tarafindan incelenmiș, iThenticate yazılımı ile taranmıș, araștırma yayın ve etiğine aykırıık tespit edilmemiștir.}

\section{BY-NC 4.0}

Bu makale Creative Commons Attribution-NonCommercial License altında lisanslanmıștır.

This paper is licensed under a Creative Commons Attribution-NonCommercial License

\section{Research \& Publication Ethics}

This article was reviewed by at least two referees, a similarity report was obtained using iThenticate, and compliance with research/publication ethics was confirmed.

\footnotetext{
Atıf/Citation

Kurban, Samed. "Çocuğun liyi Olma Hâlinin Gelișmesinde Sosyoekonomik ve Yönetsel Politikalar: Finlandiya Örneği". Akademik İncelemeler Dergisi 16 / 2 (Ekim 2021): 26-43. https://doi.org/10.17550/akademikincelemeler.921840
}

Makale Türü/Article Type: Araştırma Makalesi/Research Article

Geliş Tarihi/Date Received: 19.04.2021

Kabul Tarihi/Date Accepted: 10.09.2021

Yayın Tarihi/Date Published: 15.10.2021

ISSN: $1306-7885$

E-ISSN : $2602-3016$

Cilt/Volume: 16 | Sayı/Issue: 2 |

Yll/Year: 2021 (Ekim/October) 


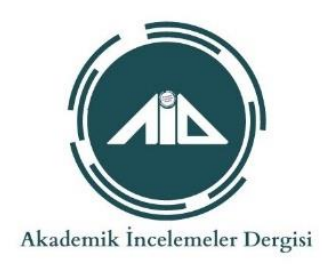

\title{
Çocuğun İyi Olma Hâlinin Gelişmesinde Sosyoekonomik ve Yönetsel Politikalar: Finlandiya Örneği
}

\section{Öz}

Son yıllarda, çocuğun iyi olma hâline odaklanan politikaların daha bütüncül bir yaklaşımla ele alındığı görülmektedir. Bunun sebebi sadece eğitim, sağllk ya da maddi yaşam koşullarına vurgu yapan sosyal refah politikalarını uygulamanın tek başına yeterli olamayacağıdır. Çünkü çocuğun iyi olma hâli çocukların bugünkü yaşamları yanında geleceklerine ilişkin durumu da içine almaktadır. Dolayısıyla, politika yapıcıların tek taraflı bir iradenin sonucu olarak uyguladığı politikalar, beșerî ve maddi kaynaklardan yeterince faydalanılamamasına yol açacaktır. Çocuğun iyi olma hâli, doğru politikaların ve yeterli düzeyde kaynak kullanımının sonucunda gençler ve yetişkinler için olumlu dışsallıklar ortaya çıkarmaktadır. Bunun için çocuklara yönelik gerek toplumsal gerekse ekonomik açıdan birtakım amaçların yönlendirilmesine ihtiyaç duyulmaktadır. Finlandiya, çocukların nesnel yaşam koşullarının ve öznel değerlendirmelerinin gelişimini olumlu yönde etkileyen yaklaşımlara sahiptir. Eğitim, sağlık, sosyal refah hizmetleri gibi temel alanlarda çocuklara yönelik uygulanan politikalar, kamunun belirleyiciliğinin başarısını ortaya koymaktadır. Temel kamu hizmetlerine ilişkin uygulanan politikalar yanında çocukların kendilerini ifade edebilmelerine imkân tanınmaktadır. Çalışma, sosyal refah hizmetleri ve yönetsel politikalar üzerinden Finlandiya'da çocuğun iyi olma hâline odaklanmaktadır. Bu bağlamda, çocuklar için daha kaliteli bir yaşamın oluşturulması sürecinde devletin üzerine düşen sorumluluğun önemi irdelenmektedir.

Anahtar Kelimeler: Kamu Yönetimi, Çocuk Hakları, Sosyal Refah Hizmetleri, Katılım, Finlandiya

\section{Socioeconomic and Administrative Policies in the Improvement of the Well- Being of Children: Finland as an Example}

\begin{abstract}
In the recent years, it is seen that the policies focusing on the well-being of children are addressed with a more holistic approach. The reason for this is that implementing social welfare policies which solely underline education, health, or material living conditions will not be enough since the wellbeing of children also includes the circumstances of the future as well as their lives today. Thus, the policies implemented by policymakers as a result of a single-sided power will lead to inefficient use of human resources and financial resources. The well-being of children ensures positive externalities for young people and adults as a result of the implementation of right policies and adequate use of resources. Therefore, there is a need to socially and economically direct certain aims regarding children. Finland has certain approaches that positively affect children's objective living conditions and the improvement of their subjective evaluations. The policies implemented for children in fundamental fields such as education, health, and social welfare services point out to the success of the decisiveness of the public. In addition to policies regarding the fundamental public services, children are provided with the opportunity of expressing themselves. Finland focuses on children's well-being through labor, social welfare services, and administrative policies. In this context, the importance of the state's responsibility in the process of ensuring a higher quality of life for children is examined.
\end{abstract}

Keywords: Social Services, Children's Rights, Social Welfare Services, Participation, Finland 


\section{Giriş}

Kamu politikası, toplumu ilgilendiren sorunların çözümü için hükümetler tarafından formüle edilen kuralları ve düzenlemeleri ifade eder. Bu yönüyle, kamu politikası kaynakları, kurumsal bağlantıları ve çıkarları çeşitlilik gösteren, kamu ve bazen de özel aktörler tarafından alınan veya uygulanan ve tabiatı gereği siyaseten kolektif olarak tanımlanan bir problemi çözmeye çalışan bir dizi kasıtlı kararları içeren bir sürecin ürünüdür (Knoepfel vd., 2007, 24). Söz konusu süreç gerek toplumsal gerekse ekonomik açıdan birtakım amaçların yönlendirilmesi ihtiyacından ileri gelmektedir. Karar alıcıların izledikleri politikalar, gerçekleştirilen eylemlerin nedenlerini ve bu eylemler sonucunda oluşan yeni durumu görmeyi sağlamaktadır. Özellikle başarılı uygulama örnekleri ile yapılacak karşılaștırmalar, pozitif öğrenme ve politika transferine imkân sağlayabilmektedir (Kutlu, 2020, 10). Buna göre, politikaların nedenleri ve sonuçları hakkında genel önermeler geliştirmek, ilgili konuda güvenilir araştırma bulguları biriktirmeye yönelik bir çabayı da destekleyecektir.

Yaş grubu bakımından nüfusun büyük kesimini oluşturan ve ekonomik, sosyal ve fiziksel açıdan savunmasız bir kesimi ortaya koyan çocuklar kamu politikasının temel konularından biridir. Birleşmiş Milletler Çocuk Hakları Sözleşmesi (1989), "onsekiz yaşına kadar her insanın çocuk sayılacağını" kabul etmektedir. Bu bağlamda, çocuklara yönelik uygulanan politikalar toplumsal yapıyı ve bu yapıya ilişkin birçok konuyu da düzenlemektedir. Sağlıklı, nitelikli bir eğitim almış ve sosyoekonomik refah düzeyi ortalamanın üzerinde bireylerin yetişmesi çocuklara yönelik uygulanan politikaların ve kaynak kullanımının bir fonksiyonudur. Çünkü uygulanacak politikalar toplumun bütününü ve çıkarlarını etkilemektedir.

Günümüzde, çocukların içinde yaşadığı fiziksel koşulları, kamu hizmetlerine erişimlerini, kendilerini etkileyen kararlara katılımını ve öznel değerlendirmelerini bütüncül olarak ifade etmek için "çocuğun iyi olma hâli" yaklaşımı tercih edilmektedir (Müderrisoğlu vd., 2013, 20). Kavramın çok boyutlu yapısı, çocuğun gelişim özellikleri nedeniyle yetişkinlerden farklı ihtiyaçlarının olmasından ileri gelmektedir. Söz konusu farklılık, çocukların toplumsal yaşamın tüm alanlarının ilişkiselliği içinde farklı durumlarla karşı karşıya gelmelerine neden olmaktadır (Semerci vd. 2012, 1). Çocuğun iyi olma hâlini tanımlamak ve ölçmek için genellikle iki duruma bakılmaktadır. İlk durum, refahı çok boyutlu bir kavram olarak ele almaktadır. Karar alıcılar, önemli yaşamsal boyutlara karar verir ve bu boyutları göstergelerle doldurur. İkinci durumda, çocukların kendi iyilik hâllerini nasıl gördükleri doğrudan kendilerine sorulmaktadır (OECD, 2019, 24). Dolayısıyla eğitim, sağlık, maddi yaşam koşulları, katılım gibi konularda uygulanacak politikaların yanında çocukların söz konusu politikalar karşısındaki öznel değerlendirmeleri de dikkate alınmaktadır.

Çocuk haklarının iki önemli boyutundan biri çocuk refahı, diğeri ise çocuk katılımıdır. Bu iki faktör aynı zamanda Çocuk Haklarına Dair Sözleşme tarafından temel prensipler olarak düzenlenmektedir. Çocuklara yönelik sosyal refah ve katılım politikaları, karar alıcıların tercihlerine bağlı olarak ülkeden ülkeye farklılıklar gösterebilmektedir. Sosyal refah politikaları ve çocuk katılımı konusunda başarılı uygulamalar ise beșerî ve maddi kaynakların daha etkin kullanımına örnek olabilmektedir. Buna karşın, çocuğun iyi olma hâli olgusunun çok boyutlu yapısı, tek bir gösterge ile bir alanın ölçülmesinin sorunlu olduğunu 
göstermektedir (Semerci vd., 2012, 15). Dolayısıyla, çalışmada çocuğun iyi olma hâlini belirleyen unsurların sınırlandırılmamış yapısı dikkate alınarak sosyal refah politikaları ve katılım temelli bir değerlendirme yapılmıştır.

İnsan odaklı politikaların yürürlükte olduğu Finlandiya'da, çocuk haklarının ve çocuk refahının bir kültür oluşturduğunu söylemek mümkündür. Bu bakımdan çocuğun iyi olma hâlinin gelişimine önem verilmektedir. Çocukların yaşam alanlarına ilişkin fiziksel koşulların iyileştirilmesi yanında kendilerini ilgilendiren konularda iradelerini göstermelerine imkân sağlanmaktadır. $\mathrm{Bu}$ bağlamda, çalışmada Finlandiya yerel yönetim sistemi üzerinden uygulanan ve çocuğun iyi olma hâlini olumlu yönde etkileyen politikaların irdelenmesi hedeflenmektedir. Öncelikle merkezi yönetim karşısında yerel yönetimin konumu değerlendirilecektir. Daha sonra çocuğun iyi olma hâli, kamusal hizmetler ve söz konusu hizmetler karşısında çocukların öznel değerlendirmeleri yönüyle irdelenecektir. Çalışma, doğru politikalar ve kaynakların etkin yönetimi üzerinden çocuğun iyi olma hâlinin gelişimine ilişkin temel önermeleri sunmayı amaçlamaktadır.

\section{Finlandiya'nın Yerel Yönetim Sistemine Bakış}

Finlandiya, kamu hizmetlerinin sunulmasında, merkezi yönetim karşısında yerel yönetimin payının ağırlıkta olduğu ülkelerden biridir. Bu bakımdan, OECD ülkeleri genelinde, yerelleşme düzeyinin fazla olduğu yönetim sistemlerinden birine sahiptir. İdari ve mali çerçevede yerel yönetim birimlerine tanınan yetki ve sorumluluklar, geniş bir özerkliği de beraberinde getirmektedir.

Finlandiya'nın yönetim yapısı, merkezi yönetim altında örgütlenmiş iki basamaklı bir yerel yönetim yapısından oluşmaktadır. Bunlar, belediyeler ve bölgesel meclislerdir (Çelen, 2013, 83). Bölgesel meclisler, bölgenin yasal ortak belediye otoritesidir. Buna göre, her yerel otorite bir bölgesel meclisin üyesi olmalıdır (CEMR, 2016, 27). Yedi bölgesel birim (Güney Finlandiya, Güneybatı Finlandiya, Doğu Finlandiya, Batı Finlandiya, Kuzey Finlandiya, Laponya ve özerklik statüsü bulunan Aaland Adaları), 19 bölge meclisi ve 310 belediye yönetsel yapıyı oluşturmaktadır (Kuntalitto, 2017).

Finlandiya Anayasası'nda yerel yönetimlerin ikili işlevinden söz edilmektedir. Bunlardan ilki, yerel yönetimlerin temel bölgesel yönetim birimi olmasıdır. İkincisi ise vatandaşların kendi kendini yönetmesine olanak sağlayan üniteler olarak işlev görmeleridir (Çelen, 2013, 88). Böylelikle, temsili kurulların ve komitelerin sisteme hâkim olması, vatandaşların çeşitli yerel kamu hizmetlerine ilişkin kararlara katılma hakkına sahip olmaları ve bu yolla hizmetlerin yürütülmesini etkileyebilmelerine olanak sağlanmaktadır. (Yalçındağ, 1996, 71). Halkı ilgilendiren kararların, halkın onayı olmadan verilemeyeceğine ilişkin bir yönetim anlayıșı söz konusudur. Bu anlayış, Kuzey Avrupa ve Germen anlayıșının bir yansıması olarak görülebilir (Kılıçoğlu - Aral, 2020, 299).

Aydınlanma süreci ve liberal düşüncenin gelişimi, Finlandiya'da yerel toplulukların kendi yaşam alanlarına ilişkin kararlara katılımlarını ve kendi kendilerini yönetmelerini içeren bir anlayışı önemli hâle getirmiştir (Bayraktar - Özservet, 2020, 337). Yerel Yönetim Kanunu'na göre belediyeler, özerklik statülerinden ötürü kendileri için seçtikleri işlevleri yerine getirecek ve kendilerine verilen işlevleri kanunla ayrı ayrı düzenleyecektir. Kanun'da, belediyelerin, bir anlaşmaya dayanarak, kendi kendilerini yönetme durumları ile ilgili olanlar dışındaki kamu görevlerini de yerine getirebileceği düzenlenmektedir (LGA, 1995, m. 7/1-2). Bu 
kapsamda, Finlandiya'da yerel yönetimlerin yerine getirdiği kamu hizmetleri şunlardır (CEMR, 2016, 26): sağlık hizmetleri (birincil, ikincil hizmetler ve diş hekimliği hizmetleri), sosyal hizmetler (çocuk gündüz bakımı, yaşlılar ve engelliler için sunulan hizmetler), eğitim (okul öncesi, ilk, orta, mesleki eğitim, yetişkin eğitimi ve kütüphaneler), kültür ve boş zaman, spor dalları, bölgesel planlama, teknik altyapı ve çevrenin (yol, enerji, su ve kanalizasyon, atık, liman ve toplu taşıma) inşası ve bakımı, iş ve istihdam, bağımsız vergilendirme hakları ve finansmanı. Söz konusu refah politikaları, idareler arası ilişkilerin esas alındığı bir yapı içerisinde uygulanmaktadır. Buna göre, parlamento yasal düzenlemeleri yaparken belediyeler söz konusu düzenlemeleri hayata geçirmektedir (Bayraktar - Özservet, 2020, 337). Bölgesel meclisler ise bölgesel kalkınma, bölgesel arazi kullanım planlaması, bölgelerin uluslararası işleri, bölgelerin ilgisini artırmak, AB yapısal fon programları ve uygulanmasının sorumluluğu, kültürel ve bölgesel geleneklerin korunması ve geliştirilmesi, zihinsel ve ekonomik refahı teşvik etmek faaliyetlerinden sorumludur (CEMR, 2016, 27). Bu kapsamda, Finlandiya'da temel kamu hizmetlerinin yerine getirilmesinde temel sorumluluk yerel yönetimlere aittir. Bölgesel meclisler de daha çok bölgesel kalkınmaya yönelik politikalar uygulamaktadır.

Merkezi bir yönetim birimi olan Maliye Bakanlı̆̆ı, yerel yönetimler ile ilgili mevzuat ve idari işlerin oluşturulmasından, temel kamu hizmetleri için merkezi yönetimden yerel yönetime yapılan transferlerden, yerel yönetim maliyesi ve görev analizlerinden ve merkezi hükümet-yerel yönetim görüşmelerinin düzenlenmesinden sorumludur (vm.fi, t.y.). Bakanlık, yerel yönetimlerin tüm faaliyet ve görevlerinin gelişimini yönlendirmektedir. Bu faaliyet ve görevlerin çoğu yerel yönetimlere kanunlar tarafından verilmektedir. Bakanlık, hizmetlerin yerine getirilebilmesi için yerel yönetimlerin finans durumlarını ve gelişimlerini takip eder ve değerlendirir. Merkezi yönetimlerden yerel yönetimlere aktarılması gereken finansmanı hesaplar ve aktarımı gerçekleştirir (Ministry of Finance, t.y.).

Finlandiya, kuzey ülkelerinin vatandaşlarına yönelik olarak sunduğu sosyal refah hizmetlerini başarıyla gerçekleştiren ülkelerden biridir. Hizmet sunumunda belediyelere tanınan özerklik, kamu politikalarının uygulanması sürecinde merkezi yönetim karşısında yerel yönetim birimlerinin daha büyük rol oynadığını ortaya koymaktadır. Yerel yönetimlere sağlanan anayasal güvencenin yanında, mecliste bulunan 200 parlamenterden 150'si yerel vekil olarak görevlendirilmiştir (Bayraktar - Özservet, 2020, 337). Bu kapsamda, kamu yönetiminin yapısal bütünlüğü içinde parlamenter bir desteğin yüksek düzeyde yerelleşmeye katkı sunması beklenebilir. Belediyeler, kendilerini ilgilendiren konular hakkında kararları kendileri vermektedir. Bundan dolayı belediyelerin sağlık, eğitim, kültür, spor, sosyal yardım, çevre, altyapı gibi çok sayıda ve çeşitli sorumluluk alanları bulunmaktadır. Belediyeler, bu hizmetlerin finansmanını yerel düzeyde aldığı gelir vergisinden ve hükümet tarafından verilen sübvansiyonlarla karşılamaktadır. Belediyeler, toplam işgücünün yaklaşık bește birini istihdam etmektedir. Belediyelerin yapmış olduğu harcamaların, GSYH içindeki payı da yaklaşık bește bir düzeyindedir (Karakurt - Ela, 2017, 32). Bu bağlamda, yerel yönetim birimlerinden birini oluşturan belediyelerin, kamu mali yönetiminin önemli bir bileșenini oluşturduğunu söylemek mümkündür. 


\section{Finlandiya'da Çocuk Haklarının Genel Durumu}

Finlandiya, çocuk hakları konusunda kuzey ülkelerinin ortalama yaklaşımına sahip bir ülkedir. Bunun yanında, çocukların doğumunun ardından başlayan süreçte, erken çocukluk gelişimine büyük önem verilir. Finlandiya, Çocuk Haklarına Dair Sözleşme’nin öngördüğü hakların kullanımı için gerekli fiziksel koşulların ortalamanın üzerinde sağlandığı bir ülkedir. Çocukların yaşı ve uygunluk derecesine bağlı olarak sahip oldukları hakları kullanmaları için farklı birtakım katılım araçları da kullanılmaktadır. Böylelikle çocukların iyi olma hâli, karar alıcıların tek taraflı iradelerinin ürünü olmaktan çıkmaktadır. Politikaların uygulanması gerek kararların alınmasında gerekse uygulanmasında çocukların da aktif bir özne olarak içinde bulundukları bir süreci yansıtmaktadır.

\section{1.Çocuk Refahı Kapsamında Sunulan Hizmetler}

Finlandiya, çocukların iyi olma hâli düzeyinin yüksek olduğu ülkelerden biridir. Çocuk hakları, ulusal ve yerel mevzuat çerçevesinde ayrıntılı olarak düzenlenmekte ve güvence sağlanmaktadır. Finlandiya'nın çocuk temelli uyguladığı politikalar, başarılı çlktılar ortaya koyan tercihlerin sonucu olarak görülebilir. Çocuk kültürünün yerleşik bir durumu yansıttığı ülkede, sosyal refah hizmetleri, çocukların ve ailelerinin refahının oldukça yüksek olmasına imkân vermektedir. Bu bağlamda, ülkenin nitelikli bir eğitim sistemi yapısı içinde öğrenme çıktılarının yüksekliği, çocukların yaşam memnuniyeti düzeyinin ortalamanın üzerinde olması, çocuk yoksulluk oranının düşüklügü gibi durumlar söz konusu kültürün ve politikaların sonuçlarından biri olarak değerlendirilebilir.

Finlandiya'da yerel yönetimler, çocuklara ilişkin politikaların hazırlanmasında ve uygulanmasında kamu yönetimi içindeki ağırlığını korumaktadır. Çocuk Refahı Kanunu'na göre; "belediyeler, çocuklara, gençlere ve çocuklu ailelere yönelik sosyal ve sağlık hizmetleri, çocuk gündüz bakımı, eğitim hizmetleri ve diğer hizmetleri düzenler ve geliștirir. Aynı zamanda, çocuk bakımı ve yetiștirilmesinden sorumludur ve çocukların, gençlerin ve çocuklu ailelerin özel destek ihtiyaçlarını araştırır. Hizmetler düzenlenirken ve geliştirilirken, çocukların ve gençlerin ihtiyaç ve isteklerine özel önem verilmelidir (CWA, 2007, m. 8/1-2)". Yerel yetkililer, çocuk refahı hizmetlerini organize etmekten sorumludur. Yetkililer, hizmetleri kendileri sağlayabilir veya dışarıdaki hizmet sağlayıcılarından satın alabilirler. Hizmetleri satın alırlarsa, hizmet sağlayıcıların faaliyetlerini denetlemelidirler. Yerel makamlar, çocukların ve gençlerin refahının iyileştirilmesi ve çocuk refahı hizmetlerinin organizasyonu ve geliştirilmesi için bir plan hazırlamak zorundadır (The Ministry of Social Affairs and Health, t.y.). Çocuk ve Gençlik Strateji Programı olarak ifade edilen plan, farklı cinsiyet ve yaş grubundaki $(0-6,7-12,13-17,18-24$, 25-29) bireyleri hedef almaktadır (Eğitim, Kültür ve Araştırma Genel Müdürlügüu, 2017, 13). Bu plan, ilgili her belediyenin konseyi tarafından onaylanır ve en az dört yılda bir gözden geçirilmelidir. Plan, çocukların ve gençlerin yetiştirildiği koşulları ve refah durumlarını kapsamalıdır (European Commission, 2017, 50). Sosyal içerme ve katılımı güçlendirmek, ayrımcılık karşıtı eylemleri desteklemek ve çocuklar ile gençlerin gündelik yaşamlarına yön verebilmelerini sağlamak Çocuk ve Gençlik Strateji Programı'nın öncelikli konularıdır (Eğitim, Kültür ve Araştırma Genel Müdürlügü, 2017, 12). Bu bakımdan, Finlandiya'da stratejik planlamaya yönelik anlayışın doğrudan çocuk haklarını ve çocuk refahını ilgilendiren yönü 
bulunmaktadır. Bu konuda, en büyük sorumluluk yerel yönetimlerin kendisine verilmektedir.

Çocuk Refahı Kanunu'na göre; çocuk refahı, çocuğun olumlu gelişimini ve refahını teşvik etmelidir. Çocuk refahı, çocuk ve aile problemlerini önlemeyi ve sorun bulunursa yeterince erken müdahalede bulunmayı hedeflemelidir. Bu kapsamda öncelikle dikkate alınması gereken çocuğun çıkarlarıdır. Çocuğun çıkarlarını değerlendirirken, alternatif önlemlerin ve çözümlerin çocuk için aşağıdaki hususları ne ölçüde koruduğuna dikkat edilmelidir (CWA, 2007, m. 4/1-2):

- Dengeli kalkınma ve refah ile insan ilişkilerinin yakın ve sürekli olması

- Anlayış ve sevginin yanı sıra çocuğun yaşı ve gelişim düzeyine uygun denetim ve bakım sağlama firsatı

- Çocuğun yeteneklerine ve isteklerine uygun bir eğitim

- Büyümek için güvenli bir ortam, fiziksel ve duygusal özgürlük

- Bağımsız olma ve büyüme konusunda sorumluluk duygusu

- Çocuğu etkileme konularına katılma firsatı

- Çocuğun dilsel, kültürel ve dini geçmişini dikkate alma ihtiyacı

Çocukların sahip oldukları hakları kullanabilmesi ve refah düzeylerinin yükselmesi için belirlenen yukarıdaki hususlar ulusal mevzuat kapsamında güvence altına alınmıştır. Bu çerçevede, çocuk hakları ve refahı ile çocuk katılımı konularını düzenleyen mevzuat, sözleşmeler, politika programları ve ulusal projelerden bazıları șunlardır (Council of Europe, 2011, 52): Yerel Yönetim Kanunu (1995), Temel Eğitim Kanunu (1998), Ortaöğretim Kanunu (1998), Finlandiya Anayasası (1999), Çocuklar için Ulusal Ombudsmanlık Kanunu (2005), Gençlik Kanunu (2006), Çocuk Koruma Kanunu (2007), Çocuk Refahı Kanunu (2007), Çocuk ve Gençlik Politikaları Programı (2007-2011), Hükümet Politika Programları (2003-...), Ulusal Katılım Projesi (1998-2002), Gençlik Katılım Projesi (2003-2007), Katılımcı Öğrenci-Aktif Okulu (2005-2007). Bununla birlikte, Adalet Bakanlığı ile iş birliği içinde çalışan, özerk ve bağımsız bir otorite olan Çocuk Ombudsmanı (Lapsiasiavaltuutettu), çocukların ve gençlerin hak ve refahını teşvik eder. Örneğin, çocuklar için ve onların hakları konusunda bir web sitesi hazırlamıştır ve çocukların sahip oldukları haklar konusunda onları bilgilendirir. Ayrıca her yıl, hükümetin çocuk ve gençlerin refahı, yaşam koşulları ve haklarının uygulanması konusundaki politikalarını ve icraatlarını izler ve raporlar. Bunun yanında dört yılda bir Parlamento'ya rapor verir (European Commission, 2017, 13-14). Çocuk Ombudsmanı, çocuk haklarının gerçekleştirilmesini değerlendirir ve teşvik eder. Çocuklara yönelik politikaların izlenmesi ve geri bildirim yapılması, çocuk haklarının geliştirilmesi bakımından oldukça önemlidir.

Finlandiya'nın eğitim, sağlık, çocuğun ve ailenin sosyoekonomik koşulları, toplumun genel refahı gibi çekirdek alanlara ilişkin uyguladığı politikaları mevzuat, hükümet programları ve projeler aracılığıyla takip etmek mümkündür. Bu durum, çocuğun toplum için sağlıklı gelişiminin ve yetişkinliğe hazırlanması sürecinin bütün yönleriyle ve titizlikle ele alındığını ortaya koymaktadır. Dolayısıyla eğitim politikası, sağlık politikası ve refah politikasının bütüncül ve sistemli bir uyumu görülebilir. Çocuğun iyi olma hâlinin gelişimi öncelikli politika konularından biridir. Finlandiya, sadece çocuğun iyi olma hâlinin nesnel koşullarının değil aynı zamanda öznel değerlendirmesinin de son derece olumlu olduğu ülkelerden biridir. PISA sonuçlarına göre, öğrencilerin yaşam memnuniyetinin en yüksek olduğu ülkelerden biri de Finlandiya'dır (OECD, 2016; OECD, 2019). Dolayısıyla, öğrenciler kendileri 
için uygulanan sosyal refah hizmetlerinden genel olarak memnun olduklarını bildirmektedir. Finlandiya'da, genel olarak, çocuklara yönelik uygulanan politikalar ve politikalara bağlı faaliyetler Tablo 1'de gösterilmektedir.

Tablo 1: Kamu Sektörünün Çocuklu Ailelere ve Çocuklara Verdikleri Hizmetler

\begin{tabular}{|c|c|c|}
\hline Temel Hizmetler & Finansal Yardım & $\begin{array}{l}\text { Aile İzni Sistemi - } \\
\text { İş ve Aile Hayatı Arasındaki } \\
\text { Uzlaşma }\end{array}$ \\
\hline Anne ve Sağlık Klinikleri & $\begin{array}{l}\text { Doğum Yardımı/Nakit Olarak } \\
\text { Toptan Ödenen Para ya da } \\
\text { Doğum Paketi }\end{array}$ & Doğum İzni ve Annelik Ödeneği \\
\hline $\begin{array}{l}\text { Erken Çocukluk Eğitimi ve } \\
\text { Bakımı }\end{array}$ & Çocuk Parası & $\begin{array}{l}\text { Ebeveynlik İzni ve Ebeveyn } \\
\text { Ödeneği }\end{array}$ \\
\hline $\begin{array}{l}\text { Okullar, Okul Sağlığı } \quad \text { ve } \\
\text { Öğrenci Refahı }\end{array}$ & Konut Yardımı & Babalık İzni ve Babalık Ödeneği \\
\hline Diş Bakımı & Sosyal Yardım & Çocuk Bakım İzni \\
\hline $\begin{array}{l}\text { Çocuk Rehberliği ve } \text { Aile } \\
\text { Danışmanlığı Klinikleri }\end{array}$ & *** & Kısmi Çocuk Bakım İzni \\
\hline Gençlik Çalışmaları & $\begin{array}{lcr}\text { Çocuk } & \text { Evde } & \text { Bakım } \\
\text { Ödeneği/Kısmi Bakım Ödeneği }\end{array}$ & \\
\hline Aile Merkezleri & Özel Gündüz Bakım Ödeneği & \\
\hline
\end{tabular}

Kaynak: (Kuokkanen - Muuronen, 2018)

Tablo 1'de görüldüğü üzere, devletin çocuklara ve ailelerine yönelik olarak sunduğu birçok hizmet vardır. Bu hizmetler, merkezi yönetim ve yerel yönetimler tarafından eşgüdüm içinde sunulur. Örneğin, eğitimde ücretsiz okul yemekleri, öğrenci refah hizmetleri ve gıda eğitimi ulusal çekirdek müfredatın ayrılmaz bir parçasıdır. Yerel düzeyde ve okul düzeyinde müfredat ise okul yemekleri düzenlemesinin temel ilkelerini tanımlar (Ministry of Education and Culture, 2012b). Merkezi yönetim, genel olarak toplumun refahı ile ilgilenmekle birlikte hizmetleri organize etme sorumluluğu yerel yönetimlere (belediyelere) aittir.

Finlandiya, çocuklara yönelik uygulanan politikalar ile kaynak kullanımını başarılı bir şekilde yöneten ülkelerden biridir. Ülkede, çocuklara yönelik yapılan yatırım harcamaları GSYH'nın yüzde 3.2'sini oluşturmaktadır (Avrupa ortalaması yüzde 2.4). Yatırımlar, tüm sosyal harcamaların yüzde 10'udur ve her bir Finlandiya vatandaşı başına 1200 Euro'nun üzerindedir (Kuokkanen - Muuronen, 2018). 2014 yılında altı şehrin, çocuk refahı hizmetlerine yaptığı toplam harcama 329.878.580 Euro'dur. Çocukları kurumsal olarak veya koruyucu aile bakımında tutmak için Helsinki 100 milyon Euro'dan biraz fazla, Espoo 38 milyona yakın, Vantaa 39 milyon, Turku 37 milyon, Tampere 27 milyon ve Oulu 21 milyona yakın harcama yapmıștır (yle.fi, 2016). Bu bağlamda, sadece altı şehrin belediyesinin yapmış olduğu harcamalar, çocuk odaklı politikalara verilen önemin sonuçlarından biridir. Finlandiya, OECD ülkeleri içinde, çocuğun ve ailenin refahına yönelik olarak en fazla kamu harcaması yapan ülkelerden biridir (Şekil 1). 
Şekil 1: GSYH’nin Yüzdesi Olarak Aile Yardımları Kamu Harcamaları, 2000-2015

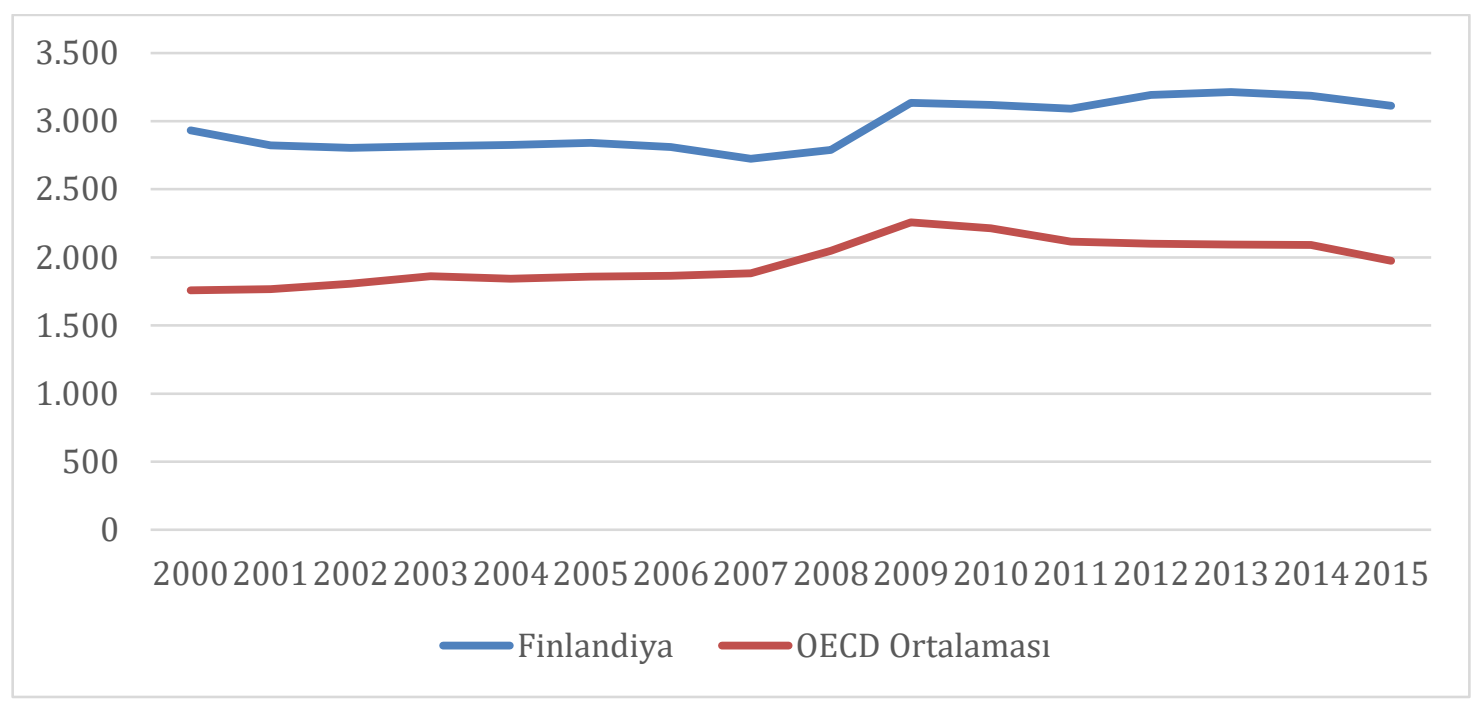

Kaynak: data.oecd.org

Şekil 1'de görüleceği üzere, 2000-2015 arası dönemde aile yardımları kapsamında yapılan harcamaların ulusal gelire oranı OECD ortalamasının üzerindedir. 2015 yılında, aile ödeneklerinin GSYH oranı, Finlandiya'da yüzde 3'ün üzerinde iken OECD ülkeleri ortalamasında yüzde 2'nin altında kalmıştır. Bakım hizmetleri, kadınların hem çocuk hem de kariyer sahibi olmalarını sağlarken istihdam oranlarının artmasına da yardımcı olmaktadır (Koçak, vd., 2017, 57). Bakım hizmetlerine ilişkin kamu harcamaları, çocuklara ve ailelere yönelik politikanın finansal kaynak kullanımı üzerinden ne şekilde uygulandığını göstermesi açısından önemlidir. Ailelere verilen sübvansiyonlara ilişkin kamu harcamaları, 0-17 yaș grubunda yoksulluk oranının düşük düzeyde kalmasına yardımcı olmaktadır. Şekil 2'de, 2016 yılında çeşitli ülkelerde çocuklara ilişkin yoksulluk oranı verilmektedir.

Şekil 2: Yoksulluk Oranı, 0-17 Yaş Yoksulluk Oranı, 2016

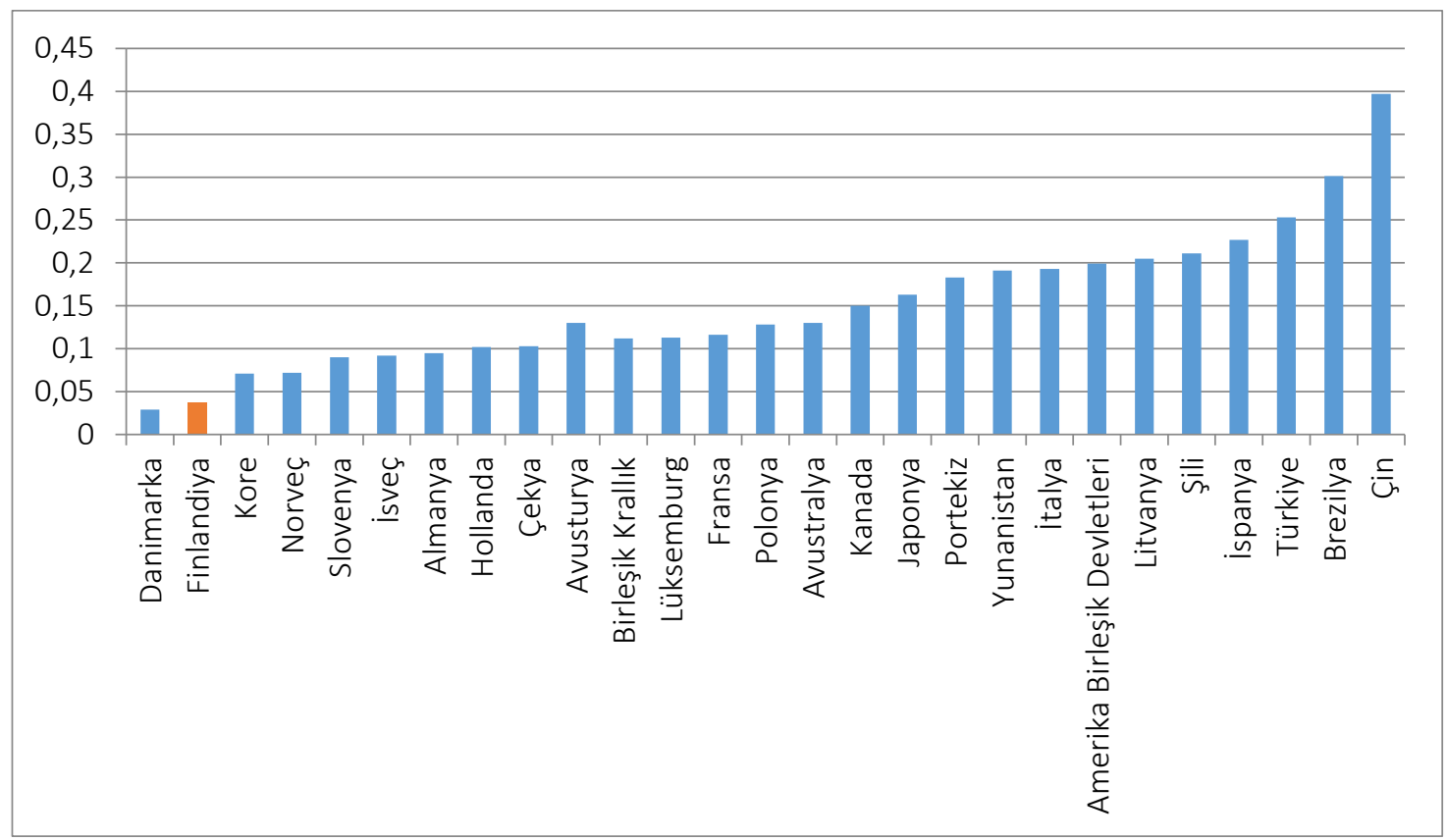


Kaynak: www.oecd.org

Şekil 2'ye göre Finlandiya, Danimarka'nın ardından 0-17 yaş grubundaki çocuklar arasında yoksulluk oranının en düşük olduğu ülkedir. Bu durum, devlet tarafından sunulan sosyal refah hizmetlerine bağlı politikaların sonuçlarından biridir. Finlandiya, sosyal faydanın toplumun her bireyi için aynı olduğu İskandinav (Nordik) modelini başarıyla uygulayan bir ülkedir. Çocuklar, güçlü bireyi var etme çabası taşıyan sosyal hizmet uygulamaları çerçevesinde yetiştirilmektedir (Kılıçoğlu - Aral, 2020, 295). Evrensel gelir garantisinin söz konusu olduğu modelde çocuklar, engelliler, yaşlılar gibi dezavantajlı gruplar için oldukça gelişmiş hizmetler sunulmaktadır (Koçak vd., 2017, 57). Bu bağlamda, çocuklara yönelik politikaların etkinliği, kaynakların yeterli düzeyde ve doğru şekilde yönetimi ile desteklenmektedir.

\subsection{Yerel Yönetime Katılım Çerçevesinde Çocuk Katılımı}

Çocukların görüşlerini serbestçe ifade edebilmeleri, görüşlerinin önemsenmesi ve tüm çocukların kendilerini ilgilendiren durumlara ilişkin karar alma sürecinde rol alabilmeleri çocuk katılımı olarak tanımlanmaktadır (Tüzün - Sarışık, 2015, 9). Bu bakımdan çocuk katılımı, çocuğun kendi yașam alanına ilişkin olarak mekân üretim süreci de dâhil olmak üzere özne olarak rol oynamasını ifade eder (Özservet, 2016, 91). Çocukların kendi yaşam alanlarını ilgilendiren konularda söz sahibi olmalarını ifade eden katılım hakkı, 1989 tarihli Çocuk Haklarına Dair Sözleșme'nin kabulünden sonra daha fazla vurgulanmaya başlanmıștır (Semerci vd., 2012, 93). Çocuk Haklarına Dair Sözleşme, çocuk katılımı için herhangi bir yaş sınırı belirtmemekle birlikte, çok küçük yaşlardan itibaren katılımın sağlanması gerektiğini ifade etmektedir (Beyazova vd., 2016, 69.). Diğer taraftan çocuk katılımı, eğitim ve öğretim süreci ile doğrudan ilintili bir konudur. Bu kapsamda, Birleşmiş Milletler Çocuk Hakları Komitesi'nin yayımladığı "Eğitimin Amaçları" konulu Genel Yorum 12'de, devletlerin eğitim politikasının her yönü ile ilgili olarak yerel ve ulusal düzeylerde çocuklara danışması gerektiği ifade edilmiştir (Tüzün ve Sarışık, 2015, 9-25).

Finlandiya Anayasası'na göre, belediye yönetimine katılma hakkı ile ilgili hükümler kanunla düzenlenmiştir. Anayasaya göre, kamu idareleri bireyin toplumsal faaliyetlere katılma ve kendisini ilgilendiren kararları etkileme fırsatlarını teşvik eder (TCF, 1999, 14). Bu kapsamda, genel olarak toplumun ve daha küçük ölçekte çocukların ve gençlerin dinlenilmesi, ulusal mevzuata yol gösterici bir ilke olarak dâhil edilmiştir. Yerel Yönetim Kanunu ve Gençlik Kanunu, şehirlerdeki sakinlerin katılım hakkını ayrıntılı olarak düzenleyen temel kanun belgeleridir.

Yerel Yönetim Kanunu'nda, "inisiyatif hakkı" başlığı altında (LGA, 1995, m. 24), yerel sakinlerin politika yapımına ve karar alma sürecine katılımlarına ilişkin konular düzenlenmektedir. Buna göre; belediye sakinleri ile belediyede faaliyet gösteren tüzel kişiler ve vakıflar, belediyenin faaliyetleri ile ilgili konularda inisiyatifte bulunma hakkına sahiptir. Bir inisiyatif sonucunda gerçekleştirilen eylem, inisiyatifi sunanlara bildirilmelidir. Belediye sakinlerinin en az yüzde ikisinin herhangi bir konuda inisiyatif sunması hâlinde, konunun başlatıldıktan sonraki altı ay içinde dikkate alınması gerekmektedir. Hizmet kullanıcıları ayrıca, söz konusu belediye hizmeti ile ilgili konularda girişimlerde bulunma hakkına sahiptir. Yerel meclis, yılda 
en az bir kez görüşü dâhilindeki konularda sunulan tüm girişimler ve bunun sonucunda alınan önlemler konusunda bilgilendirilmelidir.

Finlandiya'da yerel yönetim birimlerini düzenleyen mevzuat, katılım hakkının ayrıcalıklı bir yönünü de ortaya koyar. Yerel Yönetim Kanunu'na göre $(1995,25)$, en az 15 yaşında olan ve belde sakinlerinin en az yüzde dördünü oluşturan kişiler referandum inisiyatifi sunabilirler. Yerel meclis, referandumu yapıp yapamayacağına gecikmeksizin karar vermelidir. Temsili demokrasilerde bulunan yaş sınırı, genç insan sorununun göstergelerinden biridir. Bu çerçevede, çocukların her birinin yurttaş olarak iradelerini gösterebildiği yönetim anlayıșının oluşturulması gerekmektedir (Değirmencioğlu, 2008, 31). Finlandiya'da, yasanın referandumu düzenleyen maddesi, belediye sakinlerinin yaş grubu konusunda alt sınırı 15 olarak belirlemiştir. Bu durum Finlandiya'da, çocuk meclisi ya da çocuk komiteleri dışında, çocuğun katılım hakkının farklı bir boyutunu da göstermektedir. Buna göre, çocuklar kendilerini ilgilendiren konularda, yerel mevzuata uygun olarak belediyelerin faaliyetleri ile ilgili karar verici aktörlerden biri hâline gelmektedir. Çocuklar, kamu politikalarının uygulanması sürecinde kendi çıkarlarının korunması ve geliştirilmesi bakımından özne konumundadır.

Yerel Yönetim Kanunu, belediye sakinlerine belediyenin faaliyetleri ile ilgili konularda inisiyatifte bulunma hakkını garanti eder. Bu kapsamda, yerel yönetim sakinlerinin kolaylıkla ulaşabileceği çevrimiçi araçlar kullanılmaktadır. Belediyelerde karar verme süreci, merkezi yönetimde ve Avrupa Birliği'nde var olan yapıdan farklıdır. Ulusal ve yerel düzeyde faaliyet gösteren aktörlerin sorumluluğunda olan katılım kanalları şunlardır (www.demokratia.fi, t.y.):

Kansalaisaloite.fi: Adalet Bakanlığı tarafından yürütülen çevrimiçi hizmet, Finlandiya vatandaşlarının girişimlerini başlatmasına ve başkaları tarafından başlatılan girișimleri desteklemesine olanak tanır. Bir vatandaş inisiyatifi başlatarak mevzuatta değişiklik yapılmasını önerebilir.

Kuntalaisaloite.fi: Adalet Bakanlığı tarafından yürütülen çevrimiçi hizmet, belediye sakinlerinin, hizmeti kullanan belediyelere inisiyatif sunmalarını ve başkaları tarafından başlatılan girişimleri desteklemelerini sağlar. Sakinlerin girişimi bir belediyenin faaliyetleri veya hizmetleriyle ilgili olabilir.

Lausuntopalvelu.fi: Adalet Bakanlı̆̆l tarafından sağlanan çevrimiçi hizmet, bakanlıklar, devlet kurumları ve belediyelerdeki yerel makamlar gibi yetkililer tarafından hazırlanan konularda görüş bildirilmesine olanak tanır.

Nuortenideat.fi: Hizmet, gençlere önerilerde bulunmaları, karar alma süreçlerine katılmaları ve onları etkileyen konularda iradelerini göstermeleri için bir platform sunmaktadır. Hizmet, Koordinaatti Uzmanlık Gençlik Çalışma Merkezi, Adalet Bakanlığı ve Eğitim ve Kültür Bakanlığı tarafından sunulmaktadır.

Otakantaa.fi: Adalet Bakanlığı tarafından tutulan çevrimiçi hizmet, vatandaş girdisinin gerekli olduğu devam eden projeler hakkında bilgi içerir. Hizmetin amacı vatandaşlar, karar vericiler ve kamu yönetimi arasındaki etkileşimi arttırmaktır.

Gençler için sağlanan katılım hizmeti, gençler ve onlarla çalışan aktörlerle (örneğin gençlik konseyleri ve gençlik kuruluşları ile okullar) iş birliği içinde sunulmaktadır. Geliștirme süreci Adalet Bakanlığı, Eğitim ve Kültür Bakanlığı ile Gençlik Bilgilendirme ve Danışma Koordinaatti Uzmanlık Gençlik Çalışma Merkezi tarafından organize edilmektedir. Belediyeler, sivil toplum kuruluşları, dernekler, okullar ve etki grupları gibi aktörler bu hizmeti çalışmalarının bir parçası olarak 
kullanabilirler. (eacea.ec.europa.eu, t.y.). Yukarıdaki katılım araçlarının çoğu Adalet Bakanlığı tarafından sağlanmaktadır. Bununla birlikte, Gençlik Kanunu'na göre, ulusal gençlik politikasının genel yönetiminden, koordinasyonundan ve geliştirilmesinden ve merkezi yönetim içinde bu politikanın takip edilmesi için uygun koşulların yaratılmasından Eğitim ve Kültür Bakanlığı sorumludur (minedu.fi, 2006). Çocukların ve gençlerin katılımında gerek yerel yönetim düzeyinde gençlik oluşumları ve okullarla yapılan iş birliği gerekse ulusal düzeyde kurumlar arasında sağlanan eşgüdüm üzerinden çalışan bir sistemin olduğu görülmektedir. Buna göre çocuk katılımı, çocuk meclisleri gibi yerel yönetim düzeyinde faaliyet gösteren oluşumlar ile sınırlı değildir. Benzer şekilde, sadece yasal mevzuatta yapılacak düzenlemelerin de tek başına yeterli olamayacağı açıktır. Toplumun yönetime katılma ve inisiyatifte bulunma hakkının gerçekleşmesi ve korunması çok yönlü bir iş birliğini zorunlu kılmaktadır.

Çocuk katılımı, çocuğun ihtiyaçlarını ve isteklerini göstererek, iyi olma hâlinin tespitine yardımcı olmaktadır. Bu durum, çocukları kendi yaşamları hakkında bilgi sahibi olarak görecek bir perspektif üzerinden daha kolay bir şekilde gerçekleşebilecektir (Semerci vd., 2012, 94). Finlandiya'da, çocukların yerel kararlara katılımına ilişkin en önemli uygulama örneklerinden biri Helsinki'de görülebilir. Helsinki şehri sakinlerinin katılım ve etki yaratmasına yönelik politikalar kapsamında, katılımcı bütçeleme olarak yıllık 4.4 milyon Euro tahsis edilmektedir. Bu paranın harcanması, bölge sakinleri tarafından yapılan tekliflere dayanarak oylanacaktır. Oy kullanma yaşı sınırı 12 olarak belirlenmiştir. Ayrıca, her konut alanı için bir "şehir koçu" atanacaktır. Koç, sakinlere inisiyatiflerini teşvik etme ve önerilerini geliştirme konusunda yardımcı olmaktadır (www.hel.fi, 2020). Helsinki Katılım Modeli, çocukların ve gençlerin kendilerini ifade edebildikleri alanları meşrulaştırarak katılım düşüncesine katkı sağlamaktadır. Şehir yönetiminin, çocukları ve gençleri ilgilendiren konularda kendilerine danışması gerekmektedir (Bayraktar - Özservet, 2020, 359). Yerel hizmetlerin sunulmasında, çocukların aktif katılımının hizmetlerin daha efektif, amacına uygun ve yerine ulaşır şekilde yapılmasına yardımcı olması beklenen bir durumdur (Özservet, 2016, 122). Katılım bütçesi olarak ayrılan tutarın kullanılmasında bölge sakinlerinin tercihleri baz alınmakla birlikte, yaş sınırı 12 olarak belirlenmiștir. Bu durum, Yerel Yönetim Kanunu'nda çocukların referanduma karar vermesinde belirlenen alt sinır olan 15 yaşın altında katılım fırsatlarının olduğunu göstermektedir.

Finlandiya'da, demokratik hakların kullanımı kapsamında, çocukların ve gençlerin yaşadıkları şehir ile bütünleşmesi için katılım göstermelerinin sağlanmasına çalışılmaktadır. İlk Hükümet Çocuk ve Gençlik Politikası Programı (2007-2011), yaklaşık 300 çocuk ve gençlik politikası önlemini içermektedir. Programın odak alanı, çocukların ve gençlerin etki yaratmalarını ve seslerini duyurmalarını sağlayan sistemlerin geliștirilmesi de dâhil olmak üzere katılımlarının gerçekleștirilmesidir. Amaçlarından biri, 2010 yılı sonuna kadar tüm belediyelerde 5-17 yaş grubunun katılımını ve söz konusu yaş grubunun duyulmasını sağlayan ve farklı yaşlardaki çocukların ihtiyaçlarına ve geçmişlerine saygı duyan bir sistem uygulanmasıdır (Council of Europe, 2011, 57). 2012-2015 dönemine ilişkin Çocuk ve Gençlik Politikası Programı'nda ise "Kalkınma programının hazırlanmasının, mevcut sosyal durumda, çocuk ve gençlik politikasına üç odaklanma yoluyla yaklaşması gerektiği ifade edilmiştir: katılım, ayrımcılık yapmama ve günlük yaşam yönetimi (Ministry of 
Education and Culture, 2012a, 6)". Çocuklar için Ulusal Strateji 2040 kapsaminda belirlenen stratejilere ulaşmak için tüm topluma ihtiyaç duyulacaktır. Strateji belgesinde ifade edilen vizyon, çeşitli amaçlar üzerinden somutlaşmaktadır. Bu amaçlardan birisi de "her çocuğun, gencin ve ebeveynin topluluğun üyesi olduğu ve kendilerini topluma ait hissettiğidir. $\mathrm{Bu}$ bakımdan fark yaratabileceklerine inanılmaktadır (NSC, 2040)". Çocuk ve gençlerin istişaresi, üst düzey ulusal mevzuatta yol gösterici bir ilke olarak dâhil edildiği için sağlam bir yasal dayanağa sahiptir. Anayasa'ya göre, kamu yetkilileri bireyin toplumsal faaliyetlere katılma fırsatlarını teşvik edecek ve onu ilgilendiren kararları etkileyecektir (eacea.ec.europa.eu, t.y.). Çocukların dinlenmesi çerçevesinde geliştirilen Çocuk Dostu Şehirler Projesi'nde, Finlandiya için belirlenen hususlardan bazıları şunlardır (Nordic Council of Ministers, 2016, 33):

- Çocuk haklarını her çocuk için gerçeğe dönüştürmek

- Çocukların hedefledikleri hizmetlerin planlanması, geliştirilmesi ve değerlendirilmesinde rol oynamalarını bulma yolları

- Çocukların kamusal alanların planlanması ve geliştirilmesinde rol oynaması için yollar bulma

- Çocukların kendileri için önemli olan konuları etkileme yollarının bulunması

- Çocukların sivil etkinliklere katılma yollarının bulunması

Finlandiya'da, çocuk refahına ilişkin göstergeler ortalamanın üzerinde olmakla birlikte, çocuk meclislerinde katılım istenilen düzeyde değildir. Çocukların ve gençlerin kararlara dâhil edilmesi halâ esas olarak yetişkinlerin sağladığı yapılarda gerçekleşmektedir. Mevcut temsili yapılar, esas olarak gençleri hedeflemektedir ve küçük çocuklar için uygun olan yapılar oldukça azdır. Ulusal düzeyde çok az sayıda çocuk ve gençlik forumları vardır. Buna karşın, Finlandiya belediyelerinin yüzde 98'i, Yerel Yönetim Kanunu'nda belirtilen bir gençlik konseyi veya eşdeğer gençlik etki grubu oluşturmuştur (Ministry of Justice, 2020, 14). Çocukların, Çocuk Haklarına Dair Sözleşme kapsamında katılımımın sağlanması konusunda Yerel Yönetim Kanunu doğrudan düzenleme getirmektedir. Yerel Yönetim Kanunu’na göre; "gençlik konseylerine, belediyenin refah, sağlık, eğitim, yaşam ortamı, konaklama veya hareketliliği için önemli konularda farklı sorumluluk alanlarındaki faaliyetlerinin planlanması, hazırlanması, yürütülmesi ve izlenmesini etkileme fırsatı verilmelidir. Gençlik konseyleri, çocukların ve gençlerin katılımını ve görüşlerini sunma fırsatlarını geliştirmek için belediyenin çalışmalarına katılmalıdır (LGA, 1995, 26/2)". Gençlik Kanunu, gençlere yerel ve ulusal gençlik çalışmaları ve gençlik politikası ile ilgili konuların ele alınmasında yer almaları için fırsat verilmesi gerektiğinin altını çizmektedir. Ayrıca gençler kendileriyle ilgili konularda dinleneceklerdir (eacea.ec.europa.eu, t.y.). Bu bağlamda, Finlandiya'da Yerel Yönetim Kanunu ve Gençlik Kanunu ile gençlerin katılımına ilişkin ortak hükümler belirlenebilmektedir. Diğer taraftan şehir yönetimleri, yaş gruplarına göre farklılıklar gösterecek uygulamalar üzerinden çocukların ve gençlerin politika oluşturma ve karar verme sürecinde söz sahibi olmalarına imkân vermektedir.

\section{Sonuç ve Değerlendirme}

Kamu politikası, toplumu ilgilendiren sorunların çözümü ve devletin vatandaşlarına daha nitelikli kamu hizmetleri sunması için hükümetler tarafından formüle edilir ve uygulanır. Politikaların istenilen sonuçları vermesinde yeterli düzeyde kaynak 
kullanımı kadar sürecin doğru şekilde yönetilmesi de gereklidir. Bunun için karar vericiler, daha iyi politika oluşturmada sonuçları ve bulguları kullanarak politika oluşturma sürecini iyileștirebilirler. Çocuklar, söz konusu politikaların öznesi konumunda olan aktörlerden biridir.

Çocuğun iyi olma hâli, çocukların fiziksel ve bilişsel gelişimleri yanında toplumsal ve ekonomik boyutları olan bir olgudur. Kavram, öncelikle çocukların mevcut yaşam kalitelerinin iyileştirilmesini ifade etmektedir. Ancak iyi olma hâli, bugünün yanı sıra geleceğin koşullarının da hazırlanmasını içerir. $\mathrm{Bu}$ bağlamda, politika yapıcıların çocuğun refahına yönelik tercihlerinin belirleyiciliği ön plana çıkmaktadır. Bunun sebebi, çocuklara yönelik uygulanacak politikaların çeşitlilik gösteren ve birbiriyle doğrudan ilişkili olan kararları içermesidir. Örneğin, eğitim düzeylerinden biri üzerine uygulanan yanlış politikaların sonuçları diğer düzeyleri ve çocukların kariyer beklentileri, okul ve ebeveynleri ile ilişkileri gibi durumları etkileyebilmektedir. Benzer durum sağlık ve sosyal hizmet politikaları için de geçerlidir. Bu bağlamda, karar alıcıların, çocukların bugün ve gelecek yıllara ilişkin öznel iyi oluşlarını ortaya koyan değerlendirmelerini göz önünde bulundurması gerekmektedir.

Finlandiya, çocuklara yönelik sunduğu sosyal refah hizmetleri ve onların kendilerini ilgilendiren durumlara ilişkin söz sahibi olmalarını tanıyan yaklaşımları üzerinden örnek politikalara sahiptir. $\mathrm{Bu}$ bakımdan kamusal politikalar, temel hizmet alanlarında belirgin şekilde hissedilmektedir. Çocukların nesnel ve öznel yaşam koşullarının gelişimi için gerekli fiziksel koşullar ve ortam temin edilmektedir. Çocuğun iyi olma hâline yönelik yapılan yatırımlar, kamu politikalarının çeşitli sübvansiyonlar ile desteklendiğini ortaya koymaktadır. Söz konusu yatırımlar, aynı zamanda ailelere yönelik izlenen politikaların da bir sonucudur. Finlandiya'da çocuğun iyi olma hâlinin mevcut durumu, politika ve kaynak yönetimi ilişkisinin başarılı șekilde uyumunun sağlandığını göstermektedir. Devlet, sunulan hizmetlerin kamusal niteliğini çocukların ve ailelerinin maddi yaşam koşullarını iyileştirerek korumaktadır. Bu bakımdan eğitim, sağlık ve sosyal refah hizmetlerinde birbiriyle uyumlu politikalar uygulanmaktadır.

Çocukların, ağırlıklı olarak yerel yönetimlerin sorumluluğunda uygulanan politikalar karşısındaki öznel değerlendirmeleri kamusal tercihlerin başarısının açıklanmasına yardımcı olmaktadır. Bu konuda merkezi yönetim ve yerel yönetim arasında var olan güçlü bir iş birliğinin ve yerel yönetimlere tanınan özerkliğin de etkili olduğunu söylemek mümkündür. Eşgüdüm içerisinde çalışan kurumsal yapılar, politika kararlarının hedeflenen düzeye ulaşılmasına katkı sağlamaktadır. Merkezi yönetim ve yerel yönetim arasında sağlanan güçlü iş birliği, doğru politikalar ve uygun kaynak kullanımı üzerinden çocuğun iyi olma hâlinin gelişiminin sağlanması hedeflenmektedir. Bu bağlamda, yerel yönetim düzeyinde çocukların kendi yaşam koşullarını belirlemelerine veya iyileştirmelerine imkân tanınmaktadır. Finlandiya'da belediyeler, çocukların toplumsal yaşam içinde güçlü bireyler olarak var olmaları için yetkilendirilmişlerdir. Söz konusu yetki, kapsamlı sosyal refah politikalarının başarılı bir şekilde hayata geçirilmesiyle kullanılmaktadır. Çocukların yönetsel kararlara katılım hakkı ise yasal mevzuat tarafından korunmaktadır. Söz konusu hakkın, kamu yönetimi için daha işlevsel bir görünüm kazanması çeşitli mekanizmalar üzerinden gerçekleştirilmektedir. İnisiyatif sunma hakkı, şehir sakinlerine yönelik ayrılan bütçenin kullanımında 
çocuklara iradelerini sunma hakkının tanınması, çevrimiçi uygulama kanalları üzerinden hızlı bir şekilde sağlanan katılım gibi uygulamalar çocuğun iyi olma hâlinin sağlanmasında farklı yaklaşımlar olarak dikkat çekmektedir. Bu bağlamda, yerel yönetimlerin kamu yönetimi içinde daha işlevsel bir şekilde çalışmasının, çocuklarının iyi olma hâlinin gelişimine odaklanan stratejik planlama anlayışına katkı sunması beklenebilecektir. Sonuç olarak, uygulanan politikaların daha etkili sonuçlar vermesi mümkün olmaktadır. Finlandiya'nın toplumun dezavantajlı kesimlerinden biri olan çocuklara yönelik izlediği politikalar geleceğe ilişkin daha kaliteli bir yaşamı inşa etmektedir.

\section{Notlar}

${ }^{1}$ Hamileliğin beşinci ayında doğum yardımı için başvuru yapılabilir. Bir doğum paketi ile 170 avroluk nakit para arasında seçim yapmak mümkündür. Annelik paketi bakım ürünleri ve bebek giysileri içerir (Kela, 2019).

${ }^{2}$ Anneler, hesaplanan doğum zamanından en geç 30 gün önce doğum iznine gitmelidir. Doğum izni sırasında annelere doğum ödeneği verilir. Yaklaşık 4 ay olan toplam 105 iş günü için ödenir. Anneler hesaplanan doğum zamanından en erken 50 iş günü önce doğum iznine gidebilirler. Eğer yaparlarsa, doğum ödeneğinin ödenmesi de daha önce başlayacaktır (Kela, 2019).

${ }^{3}$ Kela, her çocuk için çocuğun 17 yaşını doldurduğu ayın sonuna kadar çocuk parası öder. Çocuk parası, ailedeki uygun çocuk sayısına göre ödenir. 2019 yllı için (Kela, 2019): ilk çocuk için aylık 94,88, ikinci çocuk için aylık 104.84, üçüncü çocuk için aylık 133,79, dördüncü çocuk için aylık 153.24, beşinci ve her ilave çocuk için aylık 172,69 Euro ödenmektedir. Bekâr ebeveynler, çocuk başına aylık 53.30 Euro'luk bir artış alır. Çocuk parası vergiden muaf gelirdir. Çocuk parası normal olarak anneye veya babaya veya çocuğun bakımından sorumlu başka bir yetişkine ödenir.

${ }^{4}$ Okul öncesi ve temel eğitim herkes için ücretsizdir ve buna okul yemekleri, öğretim materyalleri, okul taşımacılı̆̆ı ve öğrenci refahı hizmetleri dâhildir (Kela, 2019).

${ }^{5}$ Babalar en fazla 54 gün izin alabilirler, yani yaklaşık 9 hafta. Bu süre zarfında, baba aynı dönemde anne ile evde 1-18 iş günü, yani 3 hafta geçirebilir. Ailenin ikizleri varsa, 18 iş günü daha babalık ödeneği öder (Kela, 2019).

${ }^{6}$ Çocuk evde bakım ödeneği, bakım ödeneği ve bakım desteğinden oluşur. Bakım ödeneği desteği 2019 yllı için şu şekildedir (Kela, 2019): 3 yaşın altındaki bir çocuk için aylık 338,34, 3 yaşın altındaki her ilave çocuk için aylık 101,29, 3 yaşını doldurmuş ancak halen okul çağında olmayan bir çocuk için aylık 65,09 Euro ödeme yapılmaktadır.

72019 yılında, bakım ödeneğinin miktarı, günlük bakım hakkının kapsamına bağlı olarak ayda 172,25 Euro veya ayda 63,38 Euro olabilir (Kela, 2019).

${ }^{8}$ Aile yardımı harcamaları, yalnızca aileler ve çocuklar için olan mali destek de dâhil olmak üzere aile yardımlarına yapılan kamu harcamalarını ifade eder. Sağlık ve barınma gibi diğer sosyal politika alanlarında kaydedilen harcamalar ailelere de yardımcı olmakla birlikte bu göstergeye dâhil edilmemiştir. 


\section{Kaynakça}

Bayraktar, Hülya Küçük - Özservet, Yasemin Çarkırer. Finlandiya'da Gençlik Politikaları. Dünyadan Farklı Örnekleriyle Gençlik Politikaları. ed. Yasemin Çakırer Özservet - Hülya Küçük Bayraktar. 333-367. Ankara: Astana Yayınları, 2020.

Beyazova, Ayşe vd., "Eğitimde Çocuk Katılımı: Türkiye'deki Olanaklara Dair Bir Değerlendirme". Çocuk Katılımı. ed. Ercüment Erbay. 67-90. Ankara: Nobel Yayıncilık, 2016.

Birleşmiş Milletler. Çocuk Haklarına Dair Sözleşme. New York, 1989.

CEMR. Local and Regional Governments in Europe. (2018). Erişim 16 Mart 2020. https://www.ccre.org/img/uploads/piecesjointe/filename/CEMR structur es and competences 2016 EN.pdf

Council of Europe. Child And Youth Participation in Finland. Strasbourg, 2011.

CWA, Child Welfare Act. (2007). Erişim 13 Mart 2020. https://www.finlex.fi/en/laki/kaannokset/2007/en20070417 20131292.p $\underline{\mathrm{df}}$

Çelen, Mustafa. "Finlandiya'da Yerel Yönetimler". Çağdaş Yerel Yönetimler 22 (2) (2013), 83-113.

Değirmencioğlu, Serdar. "Demokrasilerde Çocuk ve Gençlere Yer Açmak". Sosyal Hizmet Dergisi. (2008), 23-31.

Eğitim, Kültür ve Araştırma Genel Müdürlüğü. Dünya Ülkeleri Ulusal Gençlik Stratejileri Raporu. Ankara: Gençlik ve Spor Bakanlığı, 2017.

European Commission. Youth Policies in Finland. (2017).

http://www.demokratia.fi/en/home/ Discover The Different Channels for Influencing. Erişim 17 Mart 2020.

http://www.oecd.org/social/family/child-well-being/data/home-environment/. Key Charts on the Home and Family Environment. Erişim 4 Nisan 2020.

https://data.oecd.org/socialexp/family-benefits-public-spending.htm. OECD Data. Family Benefits Public Spending (Indicator). Erişim 15 Mart 2020.

https://eacea.ec.europa.eu/national-policies/en/content/youthwiki/54-youngpeoples-participation-policy-making-finland. Young People's Participation in Policy-Making. Erişim 19 Mart 2020.

https://minedu.fi/documents/1410845/4276311/Youth+Act+2017/c941632115d7-4a32-b29a-314ce961bf06/Youth+Act+2017.pdf. Youth Act. 2006. Erişim 17 Mart 2020.

https://www.hel.fi/helsinki/en/administration/participate/channels/participatio n-model/. The Participation Model in Practice. Erișim 17 Haziran 2020.

https://yle.fi/uutiset/osasto/news/finnish child welfare child protection or for profit foster care/8725326. Finnish Child Welfare: Child Protection "for Profit" Foster Care? Erişim 15 Mart 2020. 
https://vm.fi/en/local-government-affairs. Local Government. Erişim 16 Mart 2020.

Karakurt, Bilal - Ela, Mustafa. "Finlandiya'da Yerel Yönetimler: Türkiye İçin Öneriler”. Çağdaş Yerel Yönetimler Dergisi 26 (3) (2017), 31-68.

Kela. Benefits for Families with Children. 2019. Erişim 15 Mart 2020. https://www.kela.fi/documents/10180/3571044/Koti+ja+perhe_esite_en_ Kela.pdf

Kılıçoğlu, Emine Arslan - Aral, Neriman. "Finlandiya'da Çocuklara Yönelik Yönetsel Örgütlenme ve Politikalar". Çocuklara Yönelik Karşılaştırmalı Yönetsel Yapılar. ed. Yasemin Mamur Işıkçı - Abdullah Dirikoç. 291-303. Ankara: Astana Yayınları, 2020.

Knoepfel, Peter vd. Public Policy Analysis. Great Britain: The Policy Press, 2007.

Koçak, Orhan vd. "Bilgi Toplumu Perspektifinde Refah Devleti: Finlandiya Modeli". Yalova Sosyal Bilimler Dergisi. 8 (13) (2007), 48-75.

Kuntalitto. Finnish Municipalities and Regions. Erişim 24 Mart 2020. https://www.localfinland.fi/finnish-municipalities-and-regions

Kuokkanen, Julia - Muuronen, Kaisu. Child Welfare in Finland. Helsinki: Central Union for Child Welfare, 2018.

Kutlu, Öner. "Kamu Yönetiminde Karşılaştırmalı Yöntem". Çocuklara Yönelik Karşılaştırmalı Yönetsel Yapılar. ed. Yasemin Mamur Işıkçı - Abdullah Dirikoç. 7-16. Ankara: Astana Yayınları, 2020.

LGA, Local Government Act. (1995). Erişim 16 Mart 2020. https://www.finlex.fi/en/laki/kaannokset/2015/en20150410.pdf

Ministry of Education and Culture. Child and Youth Policy Programme 2012-2015. Finland, 2012a.

Ministry of Education and Culture. Proudly Presents: School Meals in Finland. 2012b. Erişim 13 Mart 2020. https://minedu.fi/en/article//asset publisher/proudly-presents-school-meals-in-finland

Ministry of Finance. Local Government Finances. Erişim 18 Nisan 2020. https://vm.fi/en/local-government-finances

Ministry of Justice. Children's Participation Rights in Finland. Finland, 2020.

Müderrisoğlu, Serra vd. Çocuk Refahı Belgesi. Kalkınma Bakanlığı ve UNICEF, 2013.

Nordic Council of Ministers. Do Rights! - Nordic Perspectives on Child and Youth Participation. Ved Stranden, 2016.

NSC, National Strategy for Children 2040. Erişim 18 Nisan 2020. https://minedu.fi/en/strategy-for-children

OECD. Doing Better for Children. Paris: OECD Publications, 2009.

OECD. PISA 2015 Results (Volume III): Students'Well-Being. Paris: OECD Publishing, 2016. 
OECD. PISA 2015 Results (Volume III): Students'Well-Being. Paris: OECD Publishing, 2017.

OECD. PISA 2018 Results (Volume III): What School Life Means for Students' Lives, PISA. Paris: OECD Publishing, 2019.

Özservet, Yasemin Çakırer. "Çocuklar İçin Katılımcı Yerel Yönetimler". Çocuk Katılımı. ed. Ercüment Erbay. 91-128. Ankara: Nobel Yayıncılık, 2016.

Semerci, Pınar Uyan vd. Eşitsiz Bir Toplumda Çocukluk: Çocuğun "İyi Olma Hâli"ni Anlamak. İstanbul: İstanbul Bilgi Üniversitesi Yayınları, 2012.

TCF, The Consitution of Finland. (1999). Erişim 14 Nisan 2020. http://www.finlex.fi/en/laki/kaannokset/1999/en19990731.pdf

The Ministry of Social Affairs and Health. Local Authorities are Responsible for Organising Child Welfare Services. Erişim 13 Mart 2020. https://stm.fi/en/social-services/child-welfare

Tüzün, Işık - Sarıșık, Yaprak. Türkiye'de Okullarda Çocuk Katılımı: Durum Analizi. İstanbul: İstanbul Bilgi Üniversitesi Yayınları, 2015.

Yalçındağ, Selçuk. "Finlandiya'da Yerel Yönetimler”. Çağdaş Yerel Yönetimler 5(5) 1996, 71-83. 